\title{
El arte urbano y su patrimonialización. El caso de Huelva
}

\author{
Ana Fernández Peña | Gestora cultural \\ URL de la contribución <www.iaph.es/revistaph/index.php/revistaph/article/view/4924>
}

A partir de mi formación como gestora cultural, he desarrollado una investigación que trata específicamente sobre el fenómeno del arte urbano en sus distintas expresiones y técnicas, profundizando en sus raíces culturales y antropológicas. En particular, centrada en el estudio del arte urbano en la ciudad de Huelva, ya que, en las últimas décadas, se ha producido en ella una importante eclosión de este tipo de manifestaciones, generando un debate ciudadano de alcance muy significativo y revelador (Fernández Peña 2019).

Mis aportaciones a este tema han sido muy complejas y numerosas: desde la reconstrucción de los orígenes del movimiento grafitero en la Huelva de los años 80, todavía muy vinculado a ciertas formas de transgresión o vandalismo, hasta su posterior evolución con la explosión de murales de técnica depurada, llenos de vida y color, y la emergencia de artistas de gran talla y proyección. Estas nuevas formas de expresión reciben cada vez una mejor aceptación por parte de la ciudadanía y de las instituciones, pero no es menos cierto que, por moverse en entornos "contraculturales", con unos códigos comunicativos propios y "cerrados", también son objeto de rechazo e incomprensión por una parte de la sociedad. Los artistas de Huelva han contado con el respaldo de algunas instituciones y asociaciones culturales que apuestan por estas formas de street art y que creen en su indudable valor educativo y social, y también en su potencialidad cultural: me refiero, por ejemplo, a la antigua Casa de la Juventud, al Museo Provincial de Huelva o a la Universidad de Huelva, que han amparado a artistas como Wild Welva o Man-o-Matic, entre otros.

La investigación me permitió comprobar cómo los artistas urbanos onubenses encuentran un reconocimiento más notable a escala nacional e internacional que en su propio ámbito local, demandando ellos mismos esta valoración por distintas vías. Recientemente, por ejemplo, han planteado una propuesta de una ruta de arte urbano abierta a través de una app. Resulta decisivo, por lo tanto, desde mi punto de vista, que se produzca un feedback y una escucha activa por parte de las instituciones hacia estos artistas urbanos, superando viejas controversias conceptuales sobre la determinación de lo que es o no arte y de los formatos y espacios en los que este se debe expresar.

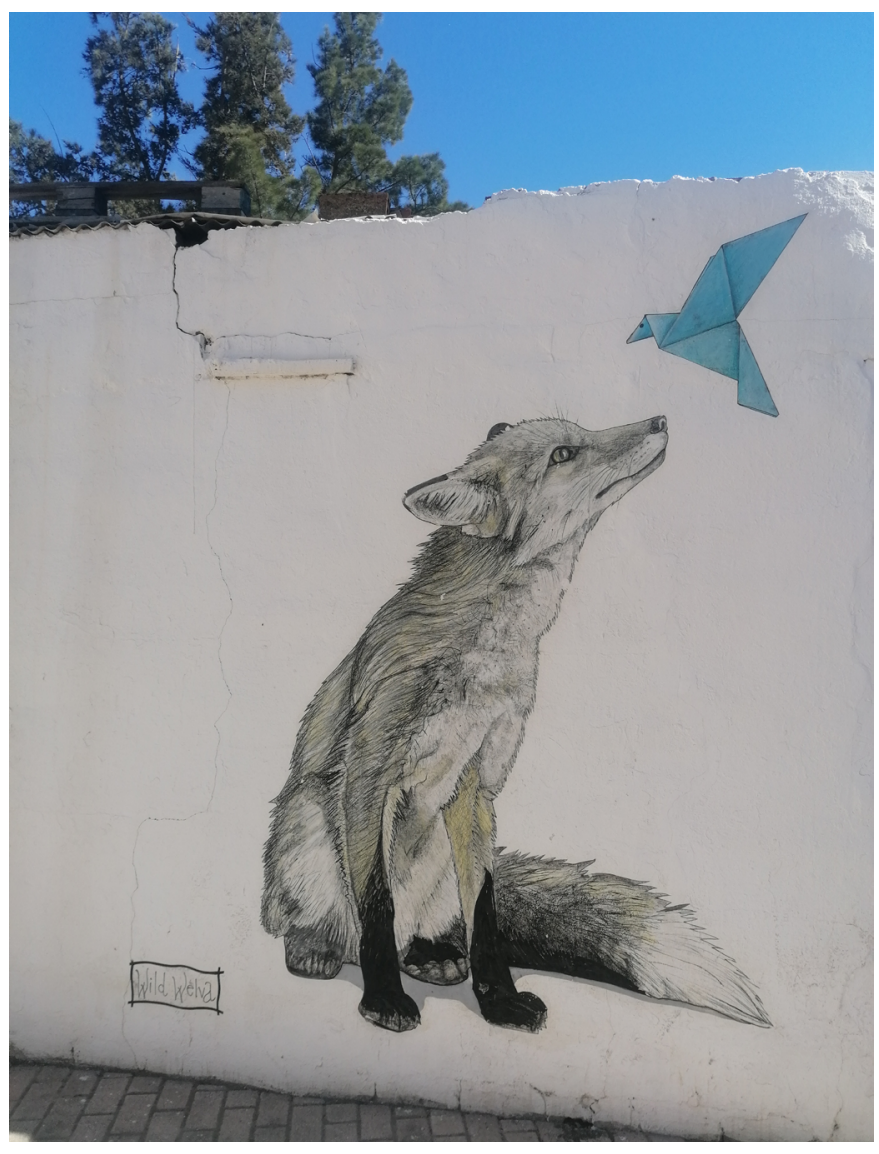

Obra de Wild Welva en avenida Sur de Huelva | foto Ana Fernández Peña 
El arte urbano puede ser considerado perfectamente patrimonio cultural de nuestras ciudades, puesto que repercute positivamente en la creación de una cultura ciudadana en la que el arte se socializa y se convierte en herramienta educativa; pero también es una práctica susceptible de ser puesta en valor, por medio de la investigación y documentación, de forma que genere plusvalías económicas a través del turismo.

En el estudio realizado también analizo la ubicación y visibilidad de las obras, así como las técnicas y materiales utilizados por los diferentes artistas, sus trayectorias, relaciones e interacciones. Igualmente, destaco aspectos como sus atribuciones ideológicas, su sesgo de género y su relación con la creciente defensa y protección del patrimonio inmueble. En especial se aborda la demanda de mayores facilidades institucionales o particulares para la obtención de los permisos necesarios para realizar sus obras.

Por otro lado, se aborda la controvertida entrada de estas prácticas en los museos y el debate que comporta. Para algunos se trata de un arte que debe ser abierto y, como su propia denominación indica, "urbano", formando parte del espacio de las ciudades y eludiendo la amenaza de que se pierda el propio sentido del mismo: esa esencia transgresora e invasiva que lo caracteriza. Surge aquí un nuevo paradigma para algunos de los artistas que afirman que el museo es algo del pasado, impropio de la identidad grafitera. Tenemos que plantarnos ante un nuevo paradigma artístico: el museo es la calle y la calle es el museo. El arte urbano se presenta como un elemento público, abierto y libre para toda la sociedad. Sin embargo, otros creen que se trata de dos hechos completamente compatibles.

El museo puede ser una parte activa en los cambios culturales y artísticos que se producen, escuchando tanto a la ciudadanía como a los diferentes actores que desarrollan estas prácticas en las calles. Un espacio que se torna en una oportunidad para los artistas de proyectar sus obras y dedicarse al arte urbano como una profesión, no solo como una afición. Para algunos artistas urbanos, el museo puede ser una forma de poner en valor su trabajo y de darle visibilidad a su marca personal, algo que les ayudaría a profesionalizarse y vivir de estas prácticas. Para el antiguo director del Museo de Huelva, Pablo Guisande, se requiere de una solvencia y trayectoria de los autores para el desarrollo de una exposición de arte urbano en el museo.

Al hilo de lo expuesto, la conservación de estas obras no tiene necesariamente que estar a cargo de una institución museística, con las dificultades que comporta su mantenimiento. Existen muchas formas de conservarlas mediante herramientas digitales y audiovisuales, aplicando nuevas tecnologías que facilitan su registro y documentación. Igualmente podrían ser fórmulas de conservación la imitación, restauración o reproducción de estas obras, incluso el registro visual y sonoro del proceso de creación, sin olvidar que las redes sociales han tomado un papel muy relevante en su difusión y promoción.

Podemos confirmar, finalmente, que el cambio se ha producido, desde la transgresión y rebeldía que caracterizaba al fenómeno hacia la profesionalización y mercantilización del mismo, y el compromiso que todos y todas debemos tener con la preservación y valorización de estas manifestaciones. En mi opinión, sería necesario que, desde la antropología, la museología y la gestión cultural, se estudiaran estas transformaciones, con rigor y desde la más absoluta responsabilidad, para poder llevar a cabo una gestión eficaz de estas expresiones artísticas, sin olvidarnos nunca de escuchar a todos aquellos los colectivos y agentes activos que forman parte en dicha gestión.

\section{BIBLIOGRAFÍA}

- Fernández Peña, A. (2019) Una aproximación etnográfica al graffiti en las calles de Huelva: Artistas, instituciones, valoraciones e incidencias. Trabajo Fin de Máster. Universidad de Sevilla 